\title{
PREVELANCE OF DIFFERENT TYPES OF ORAL HABITS AMONG SCHOOL-CHILDREN AGED 6-12 YEARS IN ALEXANDRIA (A SURVEY STUDY)
}

\author{
Sherif. H. Darwsih ${ }^{(1)}$
}

\section{ABSTRACT}

Objective: The purpose of this study is to identify the prevalence of parafunctional oral habits among schoolchildren aged 6 to 12 years in Alexandria, Egypt. Materials and methods: The study target population consisted of subjects between 6 to 12 years of age. A total of 252 Egyptian children, consisting of 158 males and 94 females were randomly examined. The examination included 1-Tongue thrusting: masseteric palpation 2-Thumb sucking: finger examination and intra-oral examination. 3-Mouth 6reathing: a. medical history. 6. Mirror test (fog test) c. Iwemen's Butterfly test. d. Water Holding Test

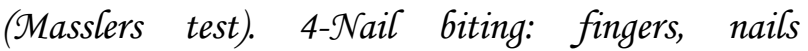
examination and intraoral examination. Questionnaires were handed out to the parents to obtain information about the child's gender, age, medical and dental history and any noticeable oral habits and collected a week later. Data was collected, sorted and registered. The subjects were assigned to different groups according to the habit. Percentile distribution of the subjects was calculated for different habit and their relation to each other, Categorical variables were analyzed using the chisquare test and Student t-test. Significance of the

1. MSc. In Orthodontics, Alexandria University obtained results was judged at the 5\% level ( $P \leq$ 0.05). Results: the majority of subjects $41.07 \%$ had nail biting followed by tongue thrust with $29.4 \%$ then mouth breathing with $15.9 \%$ and the least prevalent oral habit was thumb sucking with 15.1\%. 32.1\% of the subjects had no habits at all and 67.9\% had at least one habit. conclusion: Nail biting was the most dominant oral habit with 42.1\%., the least common oral habit was thumb sucking with 15.1\%, no patients were found practicing more than 3 habits.

\section{INTRODUCTION}

Oral health has an influence on overall quality of life [1] as it contributes greatly in general health of an individual, well-being, and psychosocial aspects. Lately, orthodontic treatment became a major concern to parents thus; Epidemiological studies are needed to monitor the prevalence of malocclusions and the need for orthodontic treatment. [2] These studies are useful in screening and to establish preventive public health plans utilizing the resources in the area.[3]

In the last two decades studies discussing the prevalence of malocclusions as well as the need for orthodontic treatment have 
been conducted for different ethnicities.[4,5,6] The reports of these studies largely varies, these differences may be due to different ethnicities but also some other factors may contribute in the vast variation including the design of the study, sample size, age group and socioeconomic status of the subjects.

A parafunctional habit can be defined as a habitual exercise of a body part in a way that is other than its intended use. These include tongue thrusting, mouth breathing, thumb sucking and nail biting. These habits are usually associated with the development of different malocclusion. Their effect is depends greatly on the type, onset and duration of the habits.[7] Thus, early diagnosis is essential in the prevention of their consequences, which encompass malocclusion, bone deformation and dentoalveolar skeletal deformation. [8,9]

Tongue thrusting is where children displace the tongue by placing it too forward or to the side, rather than resting it against the palate. This is due to the child not switching between the infantile and adult swallowing patterns. It is usually associated with anterior open bite and phonetic concerns as it causes outward fanning of the anterior teeth.[10]

Thumb sucking is the repeated nonnutritive, forceful sucking of the thumb, which is considered normal in infants and young children.[11] It is usually associated with their need for contact and security, and should disappear between ages 1-4.[11] It has been reported that $20 \%$ of children have a nonnutritive thumb sucking habit beyond the age of three years.[12] The long-term application of suction habit causes the cheeks to place inward pressure on the upper teeth, which ultimately leads to palatal constriction and posterior cross bite. Open bite is also one of its various side effects.[13] Also, the prevalence of bacterial infections was reported to be increased in children with thumb sucking habit.[14]

Mouth breathing is another serious habit. It may be caused by allergic rhinitis, recurrent throat infections, or nasal obstruction caused by adenoids or deviated nasal septum $[15,16]$ also, habitual mouth breathing is evident in some children. Under normal conditions, saliva continuously washes bacteria from the mouth. If the child's mouth is dry, which occurs as a result of mouth breathing, the bacteria can more readily aggregate, causing caries[1] and gingival disease,[18] It can also lead to permanent skeletal deformities, as it promotes the growth of the upper jaw, rather than the lower jaw, which leads to protrusion of maxillary incisors and a gummy smile.[19] It is also related to anterior open bite and abnormal speech.[20]

A child may develop the habit of nail biting as a result of anxiety, stress, boredom and the need for comfort. It may cause gingival injury, malocclusion of the anterior teeth and 
can transfer pinworms or bacteria under the surface of the nail to the mouth.[21]

Management of these habits can be quite simple, with the help of parental guidance, myofunctional therapy, habit breaking appliances and orthodontics. $[22,23,24]$ However, it could require more complex measures such as surgical intervention. [25] The method of treatment is chosen depending on the type, duration and frequency of the parafunctional habit.

The main purpose of this study is to determine the prevalence of harmful oral habits among schoolchildren aged 6 to 12 years in Alexandria, Egypt. Moreover, to raise awareness for parents to monitor their children and seek proper treatment accordingly

\section{MATERIALS AND METHODS}

Sample size calculation was done using a computer program (PS: Power and Sample Size program) Sample size was calculated assuming a 50\% prevalence ratio for any characteristic to be estimated with significance level of 0.05 .

The study was conducted in Alexandria, Egypt. The study target population consisted of subjects between 6 to 12 years of age who were attending four schools, scouts and children attending Sunday services. Students not included in the study are those who suffer from syndromes such as ectodermal dysplasia, Down's syndrome, etc. and those who have cleft lip and palate, subjects with history of orthodontic treatment were also excluded. For comparison, our study was carried out on a group of school children of relatively higher socioeconomic status. [26]

Permissions were granted from the schools' principles to conduct the examination on the children, Furthermore, a consent form was sent to the parents and was collected a week later. Parents concerns regarding the methods of examination and infection control measures were strictly addressed. A total of 252 Egyptian children, consisting of 158 males and 94 females were randomly examined. A clinical examination chart was designed (Fig 1) and three examiners carried out clinical examination using general examiner judgment and filling in the clinical examination chart for each subject. inter-examiner reliability was developed through inter-examiner reliability exercises. Kappa Coefficients were used to examine intra examiner and inter-examiner reliability, obtaining the values of 0.90 and 0.85 respectively which is considered almost perfect [27].The schoolchildren were examined in the medical room of the schools using disposable gloves, diagnostic mirrors and a small light source

\section{Clinical examination:}

\section{1- Tongue thrusting:}

Masseteric palpation: Patients were asked to sit in an upright position on the chair. Middle finger of both hands was used to palpate the masseter muscle while both thumbs were used 
to retract the lower lip. The Child is asked to swallow the saliva, minute or absence of palpable masseteric contraction along with forward positioning of the tongue protruding between the incisors were considered as tongue thrust swallowers. $[9,28]$

\section{2- Thumb sucking:}

a. Extra-oral examination: Was carried out by evaluation of fingers for redness, cleanliness, short fingernail and fibrous callus.

b. Intra-oral examination: Proclination of maxillary incisors, narrow arched palate, and posterior crossbite were assessed. [29,30,31]

\section{3-Mouth breathing:}

a. Data was obtained from the parents regarding the frequency of allergic rhinitis and tonsillitis.

b. Mirror test (fog test): A double-sided mirror is held between nose and mouth. Fogging on the nasal side of the mirror indicates nasal breathing while fogging towards the oral side indicates mouth breathing.

c. Jwemen's Butterfly test:[32] A butterfly shaped piece of cotton was placed over the upper lip below the nostrils. If the cotton flutters down it indicates nasal breathing.

d. Water Holding Test (Masslers test):[30] The patient is asked to fill his mouth with water and retain it for a period of time. While nasal breathers accomplish this with ease, mouth breathers find the task difficult.

\section{4-Nail biting:}

Extra-oral examination by observing the contour and of the nails, presence of cracks and continuity of cuticles

\section{Questionnaires:}

Questionnaires were handed out to the parents to obtain information about the child's gender, age, medical and dental history and any noticeable oral habits.

Data concerning subjects was collected from the examination charts and questionnaires, sorted and registered using Excel 2013 (Microsoft, Redmond, WA, USA) and analyzed for each habit.

\section{Statistical analysis:}

Descriptive statistics were calculated for every measured variable to evaluate the studied sample. Percentile distribution of the subjects was calculated for different habits and their relation to each other while Categorical variables were analyzed using the chi-square test and Student t-test to determine differences in prevalence rates between genders and ages. $P$ value for statistical significance was set at 0.05 . 
Figure (1): consent form, examination chart and questionnaire

Diagnostic sheet

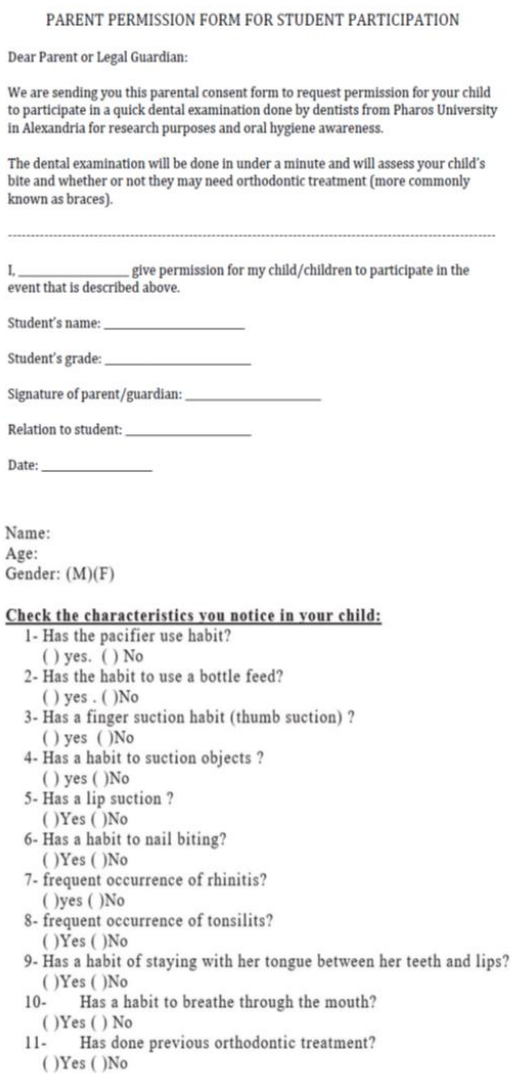

\section{RESULTS}

The present sample was of a total of 252 children, consisting of 158 males and 94 females in the age group of 6- 12 years old children. The Mean age of the population was $8.16 \pm 1.63$ years. (Table 1, Graph 1 )

I. Prevalence of each habit: the majority of subjects shows nail biting with $41.07 \%$ followed by tongue thrust with $29.4 \%$ then mouth breathing with $15.9 \%$ and the least prevalent oral habit was thumb sucking with 15.1\%. (Table 2), (Graph 2)

II. Prevalence according to the total number of habits: $32.1 \%$ had no habits at all

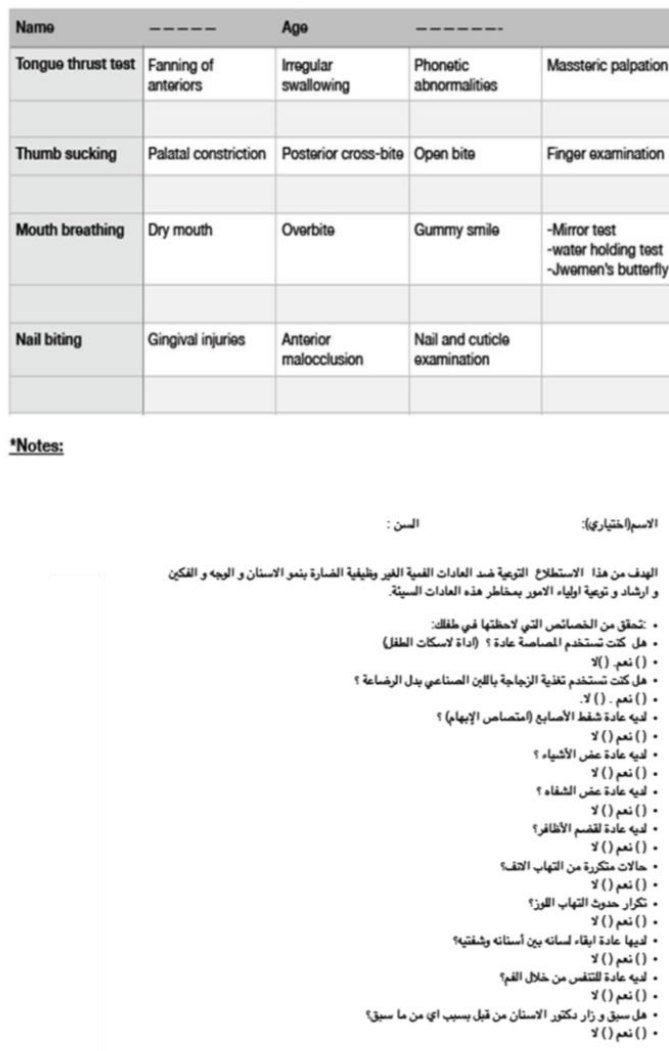

$67.9 \%$ had at least one habit including $57.3 \%$ had one habit only, $34.5 \%$ had 2 habits, $8.2 \%$ had 3 habits and none of the children had all of the 4 habits combined (Table 3), (Graph 3)

III. Prevalence according to age: student-t test showed no statistically significant difference between different age groups (Table4)

IV.Prevalence according to gender: there was no statistically significant difference between males and females except with nail biting where $46.8 \%$ of males and $34 \%$ of females had this habit. $\mathrm{p}$ value $=0.047$ (Table 5) 
Table (1): Distribution of the studied cases according to demographic data $(n=252)$

\begin{tabular}{|l|c|c|}
\hline & No. & $\%$ \\
\hline Sex & & \\
$\quad$ Male & 158 & 62.7 \\
Female & 94 & 37.3 \\
\hline Age (years) & \\
Min. - Max. & $6.0-12.0$ \\
Mean + SD. & $8.16 \pm 1.63$ \\
Median (IQR) & $8.0(7.0-9.0)$ \\
\hline
\end{tabular}

Graph (1): Distribution of the studied cases according to gender $(n=252)$

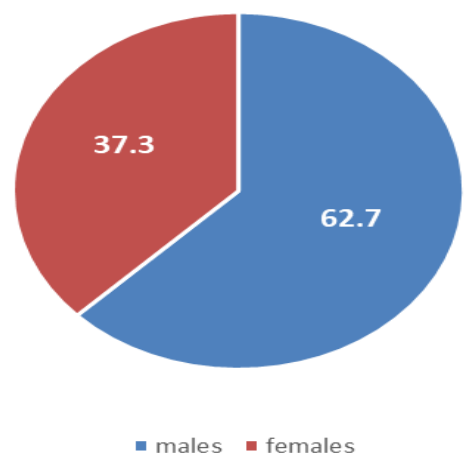

Table (2): Distribution of the studied cases according to different habits $(n=252)$

\begin{tabular}{||l|c|c|c|c||}
\hline \multirow{2}{*}{} & \multicolumn{2}{|c|}{ No } & \multicolumn{2}{c|}{ Yes } \\
\cline { 2 - 5 } & No. & $\%$ & No. & $\%$ \\
\hline Tongue thrust & 178 & 70.6 & 74 & 29.4 \\
\hline Thumb sucking & 214 & 84.9 & 38 & 15.1 \\
\hline Mouth breathing & 212 & 84.1 & 40 & 15.9 \\
\hline Nail biting & 146 & 57.9 & 106 & 42.1 \\
\hline
\end{tabular}


Graph (2): Distribution of the studied cases according to different habits $(n=252)$

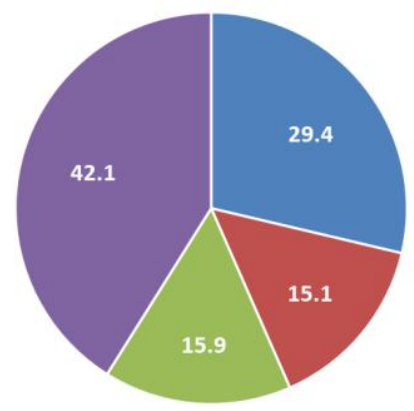

Table (3): Distribution of the studied cases according to total prevalence of oral habits $(\mathbf{n}=\mathbf{2 5 2})$

\begin{tabular}{||c|c|c|c|}
\hline Total prevalence of oral habits & No. & $\%$ & $\begin{array}{c}\text { \% from total } \\
\text { population }\end{array}$ \\
\hline No & 81 & 32.1 & 32.1 \\
1 & $\mathbf{1 7 1}$ & $\mathbf{6 7 . 9}$ & $\mathbf{6 7 . 9}$ \\
2 & 98 & 57.3 & 38.8 \\
3 & 59 & 34.5 & 23.4 \\
4 & 14 & 8.2 & 5.5 \\
\hline \hline
\end{tabular}

Graph(3):Distribution of the studied cases according to total prevalence of oral habits $(n=252)$

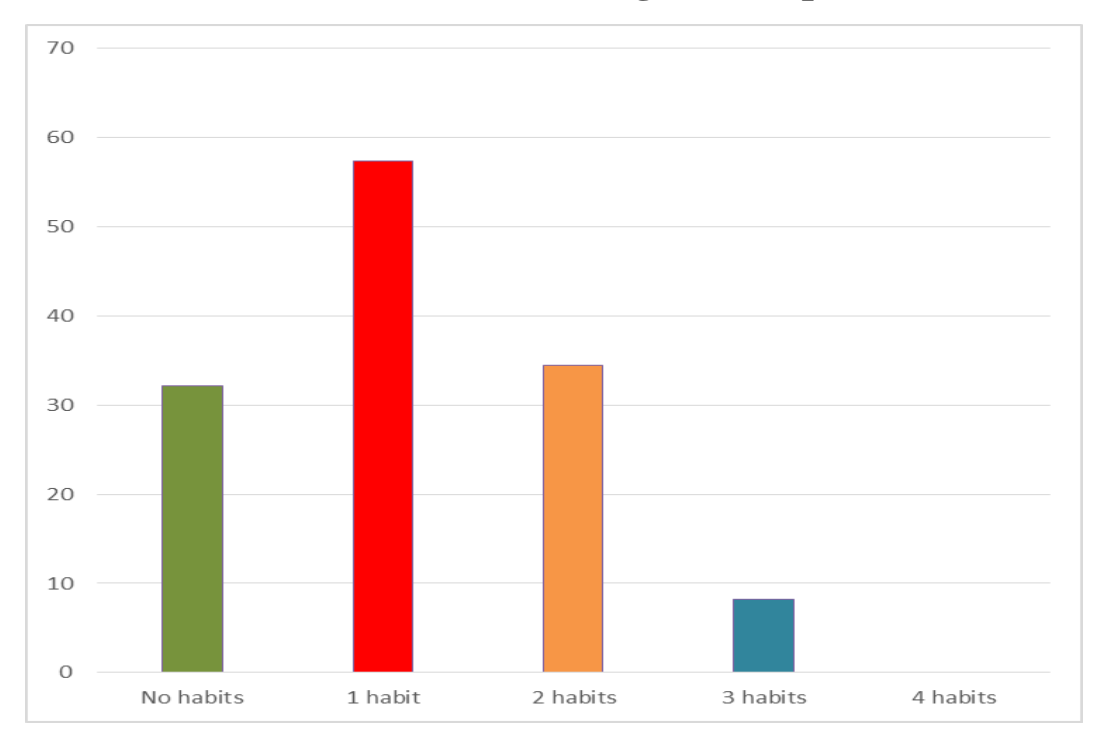


Table (4): Relation between age and oral habits $(n=252)$

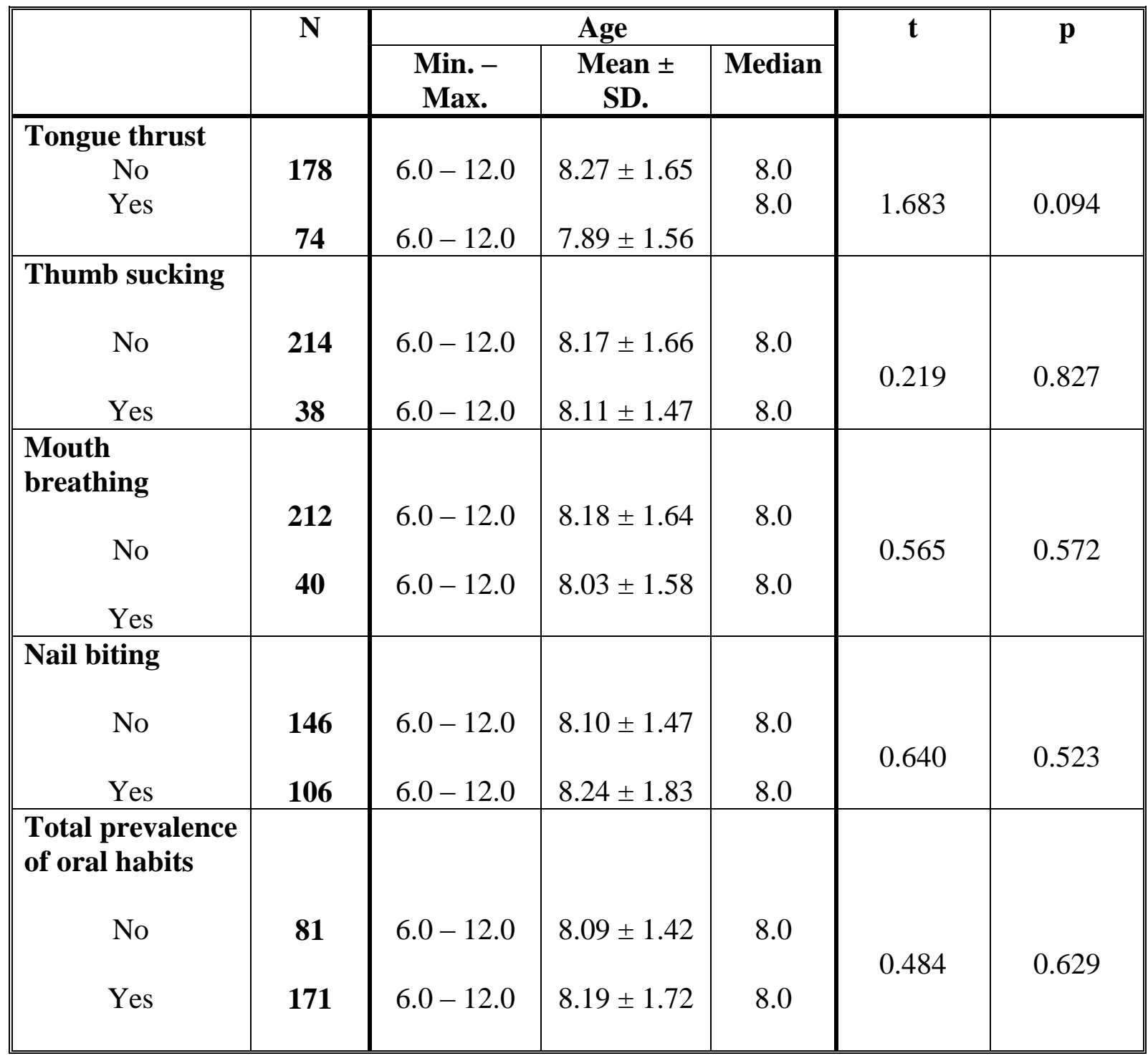

$\mathrm{t}$ : student t-test

$\mathrm{p}$ : $\mathrm{p}$ value for association between different categories 
Table (5): Relation between gender and oral habits $(n=252)$

\begin{tabular}{|c|c|c|c|c|c|c|}
\hline & \multicolumn{4}{|c|}{ Gender } & \multirow{3}{*}{ Test of Sig. } & \multirow{3}{*}{$\mathbf{p}$} \\
\hline & \multicolumn{2}{|c|}{$\begin{array}{c}\text { Male } \\
(\mathrm{n}=\mathbf{1 5 8})\end{array}$} & \multicolumn{2}{|c|}{$\begin{array}{l}\text { Female } \\
(\mathrm{n}=94)\end{array}$} & & \\
\hline & No. & $\%$ & No. & $\%$ & & \\
\hline $\begin{array}{c}\text { Tongue thrust } \\
\text { No } \\
\text { Yes }\end{array}$ & $\begin{array}{l}107 \\
51\end{array}$ & $\begin{array}{l}67.7 \\
32.3\end{array}$ & $\begin{array}{l}71 \\
23\end{array}$ & $\begin{array}{l}75.5 \\
24.5\end{array}$ & $\chi^{2}=1.733$ & 0.188 \\
\hline Thumb sucking & & & & & & \\
\hline $\begin{array}{l}\text { No } \\
\text { Yes }\end{array}$ & $\begin{array}{l}214 \\
38\end{array}$ & $\begin{array}{l}84.8 \\
15.2\end{array}$ & $\begin{array}{l}80 \\
14\end{array}$ & $\begin{array}{l}85.1 \\
14.9\end{array}$ & $\chi^{2}=0.004$ & 0.949 \\
\hline Mouth breathing & & & & & & \\
\hline $\begin{array}{l}\text { No } \\
\text { Yes }\end{array}$ & $\begin{array}{l}135 \\
23\end{array}$ & $\begin{array}{l}85.4 \\
14.6\end{array}$ & $\begin{array}{l}77 \\
17 \\
\end{array}$ & $\begin{array}{l}81.9 \\
18.1\end{array}$ & $\chi^{2}=0.549$ & 0.459 \\
\hline Nail biting & & & & & & \\
\hline $\begin{array}{l}\text { No } \\
\text { Yes }\end{array}$ & 84 & $\begin{array}{l}53.2 \\
46.8\end{array}$ & $\begin{array}{l}62 \\
32\end{array}$ & $\begin{array}{l}66.0 \\
34.0\end{array}$ & $\chi^{2}=3.958 *$ & $0.047 *$ \\
\hline $\begin{array}{l}\text { Total prevalence } \\
\text { of oral habits }\end{array}$ & & & & & & \\
\hline $\begin{array}{l}\text { No } \\
\text { Yes }\end{array}$ & 113 & $\begin{array}{l}28.5 \\
71.5\end{array}$ & $\begin{array}{l}46 \\
58\end{array}$ & $\begin{array}{l}38.3 \\
61.7\end{array}$ & $\chi^{2}=2.604$ & 0.107 \\
\hline Min. - Max. & & & & & & \\
\hline $\begin{array}{c}\text { Mean } \pm \text { SD } \\
\text { Median }\end{array}$ & 1.5 & 0.67 & & .60 & $\mathrm{t}=0.377$ & 0.707 \\
\hline
\end{tabular}

$\chi^{2}$ : Chi square test

$\mathrm{t}$ : Student t-test

$\mathrm{p}$ : $\mathrm{p}$ value for association between different categories

*: statistically significant at $\mathrm{p} \leq 0.05$ 


\section{DISCUSSION}

Parafunctional habits or Oral deleterious habits and include thumb sucking, bottle feeding, tongue thrusting, nail biting, lip biting and the mouthbreathing. These habits affects the development of the stomatognathic system and so, the overall quality of life.[1]

Psychologists consider some of these habits as normal habits in the sequence of maturation in children and children should cease these habits at certain ages. However, physical, mental stress, and socio-economic stress can cause these habits to become a problem or bad habit.[33]

The current study showed that $67.9 \%$ of the children are involved in one or more parafunctional habit which is considered midrange of the prevalence reported in different studies. The highest prevalence in the examined studies was reported by Motta et al [34] with $87.4 \%$ having oral habits. Garde et al [35] reported high prevalence of parafunctional habits with a percentage of $51 \%$ of the studied subjects. Lower prevalence was reported by Quashie-Williams [36] 34.1\%, Shetty et al [37] 29.7\%, Kharbanda et al [38] 25.5\% and Jajoo et al [26] (16.8\%), Nanda et al [39] examined children in Lucknow and reported 17\% have at least one parafunctional habit. These studies examined children roughly at the same age range, However, many factors can be involved in these vast variations in results as the design of the survey, methods of examination, sample size, ethnicity, age group and socioeconomic status of the subjects.

In the current study, prevalence of nail biting was the highest of all habits with $41.07 \%$. That comes at odds with Garde et al [35] who reported that only $5.8 \%$ of the examined subjects had nail biting habit and their results were higher than Bhayya et al [40] in children with higher age range of 11-13 years which may suggest that the higher age range is involved in reduction of the intensty of the habit. In addition to the effect of Nail biting on teeth it was repoted that it is associated with higher incidence of Enterobacteriaceae in the oral cavity.[41]

Tongue thrust was the second most prevalent habit in the current study with with $29.4 \%$. That comes in accordance with Bhayya et al [40] who reported that tongue thrusting and mouth breathing as the most prevalent oral habits. However, by examining the children in Mangalore, Shetty and Munshi [37] reported very low prevalence of tongue thrust (3.02\%).

Mouth breathing and thumb sucking was reported in $15.9 \%$ and $15.1 \%$ of the study population respectively, When examined as single habits they have the least prevalance. This comes in a partial agrement with A study done by Abou-El-Ezz A, Naseef E.H, Attia K.H [42] examining the corelation between the malcclusion and parafuntional habits reporting that $31 \%$ of the examined subjects had malocclusion associated with mouth breathing 
, $12 \%$ had a combined habit of Tongue thrust and mouth breathing, 7\% had tongue thrust habit only, and 5\% had thumb sucking habit only. The importance of comparing the results of the current study with this study is that the study population is within similar ethnic group in Egypt besides linking the prevalence of parafunctional habits to the prevalance of malocclusion.

When comparing the number of habits involved, The results shows that $67.9 \%$ were having at least one habit compared to $51.1 \%$ reported by Garde et al [35] which leads to a partial agreement. In the current study $38.8 \%$ of the subjects were found to have a single habit; $23.4 \%$ with two habits and only $5.5 \%$ with three habits. In both studies lower percentage was evident with increased number of habits.

The present study showed no significant difference in the prevalence of parafuntional habits caused by age or gender except for the habit of nail biting which was more evident in males than females. This partially agrees with Jajoo et al [26] who had statistically significant findings of habits being more prevalent in boys (18.5\%) as compared to girls (13.8\%). This also comes in agreement with Massler [33] who also observed that oral habits persisted for longer periods in boys than girls, especially tongue thrusting. Garde et al [35] reported that female children had significantly more oral habits and corelated these findings to hormonal changes and diet.

\section{CONCLUSION}

The previous results suggest that:

1. According to the different oral habits. Nail biting was the most dominant oral habit with $42.1 \%$.

2. The least common oral habit was thumb sucking with $15.1 \%$

3. According to total number of oral habits being practiced by patients. Having only one habits are the most common.

No patients were found practicing more than 3 habits.

\section{REFERENCES}

1. Barbosa TS, Gavião MB. Oral health-related quality of life in children: Part II. Effects of clinical oral health status. A systematic review. Int J Dent Hyg 2008;6(2):100-7.

2. Borzabadi-Farahani A, Eslamipuor F. Malocclusion and occlusal traits in an urban Iranian population: an epidemiological study of 11- to 14-year-old children. Eur J Orthod. 2009; 31:477-84.

3. Perillo L, Masucci C, Ferro F, Apicella D, Baccetti T. Prevalence of orthodontic treatment need in southern Italian schoolchildren. Eur $\mathbf{J}$ Orthod. 2010; 32:46-53.

4. Lew KK, Foong WC, Loh E. Malocclusion prevalence in an ethnic 
Chinese population. Austr Dent J. 1993; 38:442-9.

5. Abdullah MS, Rock WP. Assessment of orthodontic treatment need in 5,112 Malaysian children using the IOTN and DAI indices. Community Dent Health. 2001; 18:242-8.

6. Silva RG, Kang DS. Prevalence of malocclusion among Latino adolescents. Am J OrthodDentofacOrthop. 2001; 119:3135.

7. Piteo AM, Kennedy JD, Roberts RM, Martin AJ, Nettelbeck T, Kohler $\mathrm{MJ}$, et al. Snoring and cognitive development in infancy. Sleep Med 2011;12:981-7.

8. Agurto PV, Diaz RM, Cadiz OD, Bobenrieth FK. Oral bad habits frequency and its association with dentomaxilar abnormal development, in children threeto six year old in Santiago Oriente. Rev ChilPediatr. 1999;70:47082.

9. Cortese SG, Biondi AM. Relationship between dysfunctions and parafunctional oral habits and temporomandibular disorders in children and teenagers. Arch Argent Pediatr 2009;107:134-8.

10. Khinda V., Grewal N.: Relationship of tongue thrust swallowing and anterior open bite with articulation disorders. $\mathbf{J}$ IndSoc of PedoPrev Dent 1999; 17: 33 - 39.
11. Maguire JA. The evaluation and treatment of pediatric oral habits. Dent Clin North Am 2000; 44:659-69.

12. Warren J. J., Levy S. M., Nowak A. J., Tang S.: Non-nutritive sucking behaviours in preschool children: a longitudinal study. Pediatr Dent 2000; 22: 187-91.

13. Holm A. K.: A longitudinal study of dental health in Swedish children aged 3-5 years. Comm Dent Oral Epidemiol 1975; 3:228 - 336.

14. Vogel LD. When children put their fingers in their mouths. Should parents and dentists care? N Y State Dent J 1998; 64(2): 48-53.

15. Abreu RR, Rocha RL, Lamounier JA, Guerra AFM. Etiologia, manifestaçõesclínicas e alteraçõespresentesnascriançasrespirado rasorais. J Pediatr. 2008;84(6):529-35.

16. Leite RMS, Leite AAC, Friedman $\mathrm{H}$, Friedman I. A síndrome do respiradorbucalcomofator de risco para queiliteactínica. An Bras Dermatol. 2003;78(1):73-8.

17. Al-Awadi RN, Al-Casey M. Oral health status, salivary physical properties and salivary Mutans Streptococci among a group of mouth breathing patients in comparison to nose breathing. J BaghColl Dent. 2003;25(special 1):152-9.

18. Gulati MS, Grewal N, Kaur A. A comparative study of effects of mouth breathing and normal breathing on 
gingival health in children. J Indian SocPedodPrev Dent. 1998;16(3):72-83.

19. Oulis C. J., Vadiakas G. P., Ekonomides J., Dratsa J.: The effect of hypertrophic adenoids and tonsils on the development of posterior crossbites and oral habits. J ClinPediatr Dent.1994; 18 : $197-201$.

20. Dean JA, McDonald RE, Avery DA. Managing the developing occlusion. In:McDonald RE, Avery DA, (Editors). Dentistry for the Child and Adolescent, 7th ed. St. Louis, Mo:CV Mosby and Co; 2000. p. 178-217.

21. Ghanizadeh A. Nail Biting; Etiology, Consequences and Management. Iran J Med Sci. 2011 Jun; 36(2): 73-79.

22. Silva M, Manton D. Oral habits-part 1: the dental effects and management of nutritive and non-nutritive sucking. J Dent Child 2014;81(3):133-9.

23. Silva M, Manton D. Oral habits-part 2: beyond nutritive and nonnutritive sucking. J Dent Child (Chic). Sep-Dec 2014;81(3):140-6.

24. Jorge EP, GandiniJúnior LG, Santos-Pinto A, GuarizaFilho O, Castro $A B$. Evaluation of the effect of rapid maxillary expansion on the respiratory pattern using active anterior rhinomanometry: case report and description of the technique. Dental Press J Orthod 2010;15:71-9.

25. Naini FB, Gill DS. Principles of orthognathic surgical correction of skeletal anterior open bite. APOS Trends Orthod 2017;7:157-67.

26. Jajoo S, Chunawala Y, Bijle MN, Shah R, Kamble A, Gaonkar NK. Oral Habits in School Going Children of Pune: A Prevalence Study. J Int Oral Health 2015; 7(10):96-101

27. Landis, JR., \& Koch, GG. The measurement of observer agreement for categorical data. Biometrics 1977; 33, 159-174

28. Takahashi S, Kuribayashi G, Ono $\mathrm{T}$, Ishiwata Y, Kuroda T. Modulation of masticatory muscle activity by tongue position. Angle Orthod 2005;75:35-9.

29. Tendon S. Textbook of Pediatrics, 2nd ed. Philadelphia: Saunders Elsevier; 2008.

30. Marvah N. Textbook of Pediatric Dentistry, 2nd ed. Baltimore: Williams and Wilkins; 2009. p. 282-98.

31. Melink S, Vagner MV, HocevarBoltezar I, Ovsenik M. Posterior crossbite in the deciduous dentition period, its relation with sucking habits, irregular orofacial functions, and otolaryngological findings. Am J OrthodDentofacialOrthop.

2010;138:32-40.

32. Moyers RE. Etiologia da máoclusão. In: Moyers RE. Ortodontia, $3^{\text {a }}$ ed. Rio de Janeiro: Guanabara Koogan; 1991. p. 127-40.

33. Massler M. Oral habits. Origin, evolution and current concept in 
management. Alpha Omegan 1963;56:127-34.

34. Motta LJ, Alfaya TA, Marangoni AF, Agnelli R, Mesquita-Ferrari RA, Fernandes KP, Bussadori SK. Gender as risk factor for mouth breathing and other harmful oral habits in preschoolers. Braz J Oral Sci 2012; 11(3):377-80.

35. Garde JB, Suryavanshi RK, Jawale BA, Deshmukh V, Dadhe DP, Suryavanshi MK. An epidemiological study to know the prevalence of deleterious oral habits among 6 to 12 year old children. J Int Oral Health. 2014;6(1):39-43.

36. Quashie-Williams R, Dacosta $\mathrm{OO}$, Isiekwe MC. The prevalence of oral habits among 4 to 15 year old schoolchildren in Lagos. Niger J Health Biomed Sci 2007;6(1):78-82.

37. Shetty SR, Munshi AK. Oral habits in children: a prevalence study. $\mathrm{J}$ Indian SocPedodPrev Dent 1998;17(2):61-6.
38. Kharbanda OP, Sidhu SS, Sundaram KR, Shukla DK. Oral habits in school going children of Delhi: a prevalence study. J Indian SocPedoPrev Dent 2003;21(3):120-4.

39. Nanda RS, Khan I, Anand R. Age changes in the occlusal pattern of deciduous dentition. J Dent Res 1973;52:221-4.

40. Bhayya DP, Shyagali TR. Prevalence of oral Habits in 11-13 yearold School Children in Gulbarga city, India. Virtual J Orthod 2009;8(3):1-4.

41. Chinnasamy A, Ramalingam K, Chopra P, Gopinath V, Bishnoi GP, Chawla G. Chronic nail biting, orthodontic treatment and Enterobacteriaceae in the oral cavity. J Clin Exp Dent. 2019;11(12):e1157e1162.

42. Abou-El-Ezz A, Naseef EH, Attia KH. Prevalence of Mouth Breathing as etiologic factors of malocclusion in a group of Egyptian School Children. Egypt Dent J. april 2006; 52(2): 703-6 